\title{
THE BREAKING DOWN OF CONTEMPORARY STATE NEUTRALITY: THE CASE OF SWEDEN'S NON-ALLIANCE
}

\begin{abstract}
This article is a review and its main purpose is to show the evolution of the idea of neutrality as well as its contemporary understanding in selected cases. At the present time traditional neutrality seems to be an anachronism, and its contemporary forms are an expression of the adaptation of states to changing international conditions. The evolution of the concept began with neutrality abandoning its economic dimension and then reducing its military one. The distinction between war and conflict in the UN's sense gave the neutral state the opportunity to participate in armed intervention, which in reality meant shifting from neutrality towards non-alliance. For example, Sweden is playing a specific political game to gain benefits from neutrality.
\end{abstract}

\section{Key words}

evolution of neutrality, neutrality policy, military neutrality, Sweden's non-alliance 


\section{Introduction}

Dynamic changes in the post-Cold War international milieu, new security challenges and no clear criteria for the contemporary understanding of neutrality suggest various developments in the concept. States accepted to be neutral de jure while those neutral de facto shape elements of their neutrality independently, adjusting them to contemporary security challenges. As a consequence, they create their own 'models' of neutrality which are accepted (or not) by other states.

The present paper is a review, and its main aim is to show the evolution of the idea of state neutrality and its contemporary incarnations, while referring to the practice of selected countries, primarily Sweden. The paper constitutes an attempt at addressing some research questions: How did the concept of neutrality evolve from the traditional to the contemporary one? What factors had an effect on this evolution in the second half of the $20^{\text {th }}$ century, and what factors influence it at present? Moreover, presenting the phenomenon of Swedish neutrality requires asking further questions: is the current post-neutrality/non-alliance of Sweden permanent?; can contemporary security challenges entice this state to abandon its idea of neutrality?

\section{Terminological issues}

Neutrality (from Latin neuter - indifferent, none of two) denotes an impartial attitude of a state towards an ongoing military conflict and a status embraced by a state faced with war. The main characteristic of this attitude is refraining from warfare, and its main aim is to ensure the neutral state's territorial integrity, survival and development. It needs emphasizing that neutrality has primarily a peacemaking function, as it is one of the ways to maintain security.

The idea of neutrality appeared in Antiquity when the Greek polis, which lived off trade, adopted an impartial position towards ongoing wars. They did this because they believed that nothing was as harmful to trade as war. The idea of neutrality is closely related to the problem of war. Since fighting began there have been individuals and groups who have striven to avoid participating in war. It needs to be added that a neutral attitude, however, has brought about animosity in the warring factions who have demanded the neutral state support one or other of them. Interactions between a warring faction and a neutral one, 
were based on shared interests and a mutual understanding of rights and duties. Sometimes this assumed the form of an agreement written down between the warring and the neutral party (Karsh, 1988, pp. 11-19). Neutrality is thus an attitude and a status which is to protect the state and make it possible to keep out of ongoing wars, which in consequence brings particular benefits, for instance trade-related.

The $19^{\text {th }}$ century witnessed the first attempts at regulating the status of a neutral state during both war and peace. They concerned the Swiss Confederation, and were passed during the Congress of Vienna. On 20 March 1815, a declaration accepting Switzerland's neutrality was announced and it could not take part in any war, apart from a defensive war. It, however, could have its own army, lead appropriate defensive preparations and, if necessary, use force to defend its neutrality. Focus on the military aspects of the idea of neutrality can be termed as military neutrality or armed neutrality.

These considerations show that neutrality does not automatically mean demilitarization and prohibiting the maintenance of an army. Yet such a situation can sometimes occur, as can be seen in the cases of Liechtenstein and Costa Rica. A neutral state should not undertake any obligations which would lead it into war, yet like every other country it enjoys total freedom within boundaries of accepted international legal obligations. It can use its right to self-defense. With its defensive potential it can deter and discourage a potential belligerent from infringing its neutrality.

A state declares neutrality, yet it is equally significant that other states accept it. Such an acceptance is a one-sided act in which a given state or group of states (individual or collective) announce or silently admit that they accept a given state of affairs (neutrality), with all the ensuing consequences. Thus, for the international legal obligations to be effective, it is essential for other states to accept the neutral status. The wider the range of acceptance (expressed via the number of states and their importance in the international arena), the easier it is to implement the neutrality policy announced.

From the formal perspective, the kinds of neutrality most often distinguished are temporary or permanent. Temporary neutrality, also called war neutrality (in case of war, during war, for the time being), determines how the state acts in a war. This is an obligation on the state not to get engaged in a current conflict, nor to support any of the sides, and to treat them all equally. In other words, it is an idea of military neutrality. Due to circumstances, the neutral state can abandon its neutrality and, for instance, actively enter the conflict. Such a situation occurred in the case of the USA, which at the beginning of each of the world wars 
in the $20^{\text {th }}$ century announced its neutrality (in August 1914 and in September 1939), yet later abandoned it (respectively, in April 1917 and in December 1941).

Permanent neutrality (constant, eternal, neutrality during peace) defines a situation in which a state obliges itself never to participate in any war between other states, never to make any commitments which could push it into war, never to agree to host military bases and foreign armies on its territory, as well as not to allow such armies to march through its territory (or by air or water). It needs emphasizing that international law does not unanimously solve the issue of establishing the rules of permanent neutrality. The basic condition of its international legal effectiveness is acceptance. Examples of such states currently include Switzerland (since 1815), the Vatican (since 1929) and Austria (since 1955). It should be added that some states unilaterally announced permanent neutrality, developed from their own unique models, which are, however, not accepted by everyone. This group includes Costa Rica (since 1983), Moldova (since 1994) and Turkmenistan (since 1995). This last situation is unusual as Russian troops are stationed on its territory.

States can also be distinguished which lead to a politics of neutrality which is stable and peace-oriented. The concept of neutrality constitutes the foundation, determiner and main assumption of their foreign and security policies. They treat neutrality as a rule which expresses their will, not only a duty which results from international or national regulations. It can be assumed that these states are in fact neutral and accepted as such by other states, although there are no international legal acts which would sanction this situation. Taking into consideration their specificity, this group includes Sweden, Finland and Ireland. Additionally, sometimes it is said to encompass the so-called microstates, that is small independent states which maintain special relationships with their protector state. They do not have their own armies which is why the protector state obliges itself to defend the microstate. These include Monaco (and its relationship with France), San Marino (and Italy), Andorra (protected by Spain and France) and Liechtenstein (and Switzerland).

\section{Neutrality in the contemporary international order}

After World War II, neutral states faced a fundamental dilemma: did membership in the common international security system, established as part of the United Nations, violate their neutrality? The issue concerned mainly the consequences of such membership, for instance the need to participate in sanctions established by the United Nations Security Council. 
This dilemma was first solved by Sweden, which accepted the superiority of UN decisions over its neutrality, and became a full member of this organization in 1946. Sweden however revised its approach to neutrality, deciding to separate its military and economic spheres. As a consequence, its membership of the UN allowed Sweden to participate in non-military sanctions imposed by the UNSC on states which break international law. Sweden combined neutrality with an active role on the international stage, for instance through its contribution to disarmament processes, conciliation or good offices missions. This resulted from the concept of so-called security through cooperation (cooperative security) as a way to ensure international security. Sweden treats the UN as one of the pillars of establishing and maintaining peace in the world. A similar position was later embraced by Austria and Finland, on becoming members of the UN in 1955. When it comes to Switzerland, after the referendum of March 2002, in which $54.6 \%$ of the Swiss voiced their support for joining the UN, it did so in September of the same year. In its statement of UN membership, was written: "Switzerland is a neutral state whose status is based on international law. Even as a member of the UN, Switzerland remains neutral" (DPPS, n.d., p. 9).

The fundamental transformations in the 1990s related to the end of the Cold War and the collapse of the bipolar system of international relationships constituted another challenge to the concept of neutrality. Its traditional understanding, shaped on the basis of Swiss tradition and some Hague Conventions, did not correspond to the international reality of the late $20^{\text {th }}$ century. In the debate then one could even hear voices undermining the sense of the institution of neutrality in post-Cold War international reality (Joenniemi, 1993, pp. 289-304). In the case of neutral states in Europe there was an additional challenge through deepening integration processes. For many years the dominant approach was that neutrality and economic integration were mutually exclusive. Concurrently, awareness has increased that remaining outside the main current of integration processes posed a threat of economic isolation which might thwart development and weaken the position of such a state. As a result Sweden excluded economic matters from the sphere of neutrality. In 1995 Sweden, Finland and Austria joined the European Union. Rejecting the principles of economic neutrality in fact meant reducing the status of a neutral state to military obligations.

Neutral states also gradually changed their attitude towards war and military conflicts. This was a consequence of, among others, a new perception of the importance of military power, now more commonly treated as a means of ensuring security. Military forces started to be a tool in realizing "peacemaking functions," useful when human rights needed defending or international terrorism 
had to be opposed. Prioritizing human rights over the state's sovereignty and not interfering in its internal affairs made way in international law for the institution of humanitarian intervention.

Moreover, military conflicts have also changed with regard to their character. Over the years there have been fewer and fewer "classical" wars than in the $19^{\text {th }}$ century when the concept of neutrality developed. Traditional wars became replaced with "inner conflicts" and quasi-wars, while military conflicts acquired new features. Among them, the multiplicity and variety of their origins, the ease of entering the phase of armed conflict, difficulties identifying sides in the conflict, the complicated system of power involved, non-compliance with the legal conventions of war, the generation of uncontrolled mass movements of people etc., can be enumerated. New threats also determined the new situation, among them terrorism and cyberterrorism, international organized crime and hybrid wars. Employing armed forces with international consequences ceased to be the domain of states, and non-state bodies have become participants of international relationships. Thus a traditional state-centered approach to modern international security has been abandoned.

In this context, it is essential to answer the question: can obligations resulting from membership in the UN or the EU result in actions conflicting with the idea of neutrality? To put it bluntly, can activities such as participation in military sanctions imposed by the UN or the EU be reconciled with the idea of neutrality?

A position perceiving every conflict as a war was rejected and this meant that a possibility of a neutral state participating in a military conflict was admitted, which in turn meant a shift in understanding from neutrality towards nonalliance. Being a part of the UN system of states and regional systems (such as the EU) could be reconciled with the obligations of a neutral state. Thus, a gap was filled between a wish to actively participate in international affairs, including being a part of common security systems, and a wish to remain unengaged, keep a distance, or even remain isolated, which naturally stems from the idea of neutrality (for more, see Karsh, 1988, pp. 104-129).

\section{The breakdown of Sweden's policy of neutrality}

The main factor which encouraged Sweden to embrace the idea of neutrality was its historical experience. The politics of avoiding conflicts and not participating in WWI and WWII brought Sweden considerable economic benefits and development. This was additionally facilitated by its geographical location which 
made it a peripheral state, distanced from wars waged on the continent (for more, see: Malmborg, 2001, pp. 110-147; Kobierecka, 2016, pp. 142-146).

Swedish so-called military neutrality is based on the combination of the rule of no military engagement and the maintenance of a strong army with an effective system of conscription and training as deterrents. The country is relatively self-reliant when it comes to producing weaponry, as only $20-30 \%$ of its army's equipment is imported (Popławski, 2013, p. 71). Sweden is also a major exporter of armed equipment. Although in the recent years its share in arms exports has dropped (from $2 \%$ to $1 \%$ ), this is mainly an effect of other countries increasing their production. Considering arms export per capita, Sweden is one of the top countries and among the buyers, for instance in 2017, were Norway, the USA, Japan and Latvia (Statista, 2019; Wezeman, Fleurant, Kuimova, Tian \& Wezeman, 2018). Sweden was the $15^{\text {th }}$ largest arms exporter in $2014-18$, having been the $7^{\text {th }}$ largest in 1999-2003 (Wezeman et al., 2019, p. 7).

During the Cold War, expenses on defense constituted 3-4\% of Swedish GDP, the army had 75-100,000 soldiers, and military service was compulsory, while the number of trained reservists reached 750,000 , that is $10 \%$ of the population. When the Cold War came to an end and it seemed that the post-Cold War international order was stable, Sweden's defense expenses were gradually reduced, in 1989 to $2.5 \%$ GDP, in 2000 to $1.9 \%$, and in 2015 to $1.1 \%$. Because of budget cuts, a number of barracks (e.g. on the strategically located Gotland), airfields and weaponry depots were closed. In 2010, the current army was replaced with a professional army which was reduced to 13-15,000 soldiers, with about 200,000 reservists and over 20,000 territorial soldiers (Popławski, 2013, pp. 132-133; Sobczyk, 2015, pp. 45, 50-51).

In line with the collapse of the bipolar world order, Sweden, in fear of excessive political isolation, increased its activity on the international stage in the structures of the UN, EU, OSCE, and also NATO. In 1994, as the first neutral state, it joined the Partnership for Peace program; it also participates in the Euro-Atlantic Partnership Council established in 1997. Sweden is an active participant of international cooperation for ensuring security, and among other actions sending its military forces on various missions. For instance, in 2003, executing the UN mandate, Swedish troops participated in the EU military operation "Artemis" in the Democratic Republic of Congo. Since 2003, Sweden has been sending its troops to Afghanistan as part of the International Security Assistance Force, and in 2011 JAS Gripen aeroplanes took part in the NATO operation "Unified Protector" in Libya (NATO, 2013). It is worth noting that Sweden established rapid reaction forces, as well as the Nordic Defense Cooperation 
(NORDEFCO) whose aim is to increase the defense potential of Denmark, Finland, Iceland, Norway and Sweden. This cooperation was confirmed in practice by establishing the Nordic Battlegroup whose core includes about 1000 Swedish soldiers. At present, Swedish forces serve in over 20 countries with more than 400 soldiers are on duty (Swedish Armed Forces, 2017). In 2019 more than 300 Swedish soldiers (experts, officials, police etc.) are deployed on United Nations peacekeeping operations. Swedish peacekeepers are deployed on nine missions (United Nations Peacekeeping, n.d.).

In 2002, the Swedish government made a historic decision and removed the reference to neutrality from its security policy, replacing it with non-alliance (remaining outside any military alliances) coupled with its increased defense potential and active international cooperation. A further modification of Swedish policy was brought about by an increasing security deficit caused, among other factors, by a cyberattack on Estonia in 2007, war between Russian and Georgia in 2008, progressing militarization of the Arctic and numerous provocations on the part of Russia (e.g. a simulated attack of strategic bombers Tu-22M on Stockholm in 2013, simulated landing operation on Gotland in 2015, and submarine maneuvers near Stockholm in 2017 and 2018). Russia perceives Sweden as an integral part of the West and an informal part of NATO, with which Sweden has unofficially been cooperating for years. The tradition of this cooperation goes back to the Cold War, when as part of the "Nordic Balance" Sweden tried to play the role of a key moderator in Cold War confrontation in the Baltic region. According to some scholars, such undertakings proved that Sweden's neutrality then was in fact an illusion, as the state was acting as an unofficial member of the treaty organization (Bjereld \& Ekengren, 2004, pp. 143-154).

The Swedes are aware that their resort to neutrality will not be respected by Russia if a conflict in northern Europe occurs, although Sweden formally has non-alliance status and is not a member of NATO (Bildt, 2018). On the other hand, from the perspective of the USA and its allies, Sweden (just like Finland) is an extension of the northern flank of NATO. Increased American military presence in this region is to be a signal for Russia that any attempts to use the Swedish and Finnish territory in belligerent acts in the Nordic-Baltic region will meet with an American response (Gotkowska \& Szymański, 2016). Possible membership of Sweden in NATO in the future would be a defeat for Russian foreign policy, as on a number of occasions Moscow has tried to stop the Nordic expansion of NATO and sees the extending of the organization in this region as a threat to its vital interests. At the same time, this might be an argument against admitting Sweden to NATO, as its membership might lead to an unpredictable 
reaction from Russia. Sweden fears that its membership of NATO might have negative consequences (from Russia's side) for neighboring Finland (Chaney, 2017, p. 38). From Moscow's perspective, Stockholm and Helsinki might be perceived as NATO's allies who do not have any guarantee of collective defense or use of the military deterrents, guaranteed in Article 5 of the Washington Treaty (Chaney, 2017, pp. 53, 63).

Another event that led to a considerable change in Swedish policy was Russian military intervention in Ukraine and the forceful takeover of the Crimea in 2014. This event undermined the foundations of European security. According to A Global Strategy for the European Union's Foreign and Security Policy: "However, peace and stability in Europe are no longer a given. Russia's violation of international law and the destabilisation of Ukraine, on top of protracted conflicts in the wider Black Sea region, have challenged the European security order at its core" (EEAS, 2016, p. 33). This event also undermined the foundations of Swedish security policy as conducted thus far. The latter assumed that there was no threat to the country from a conventional military conflict. As a consequence, Sweden supported implementing sanctions against Russia and is still strongly in favor of maintaining them. In 2015, the Swedish parliament passed Defense strategy in 2016-2020, which assumed that expenses for defense would gradually increase by $2.2 \%$ annually, and that cooperation with Scandinavian countries (especially Finland), other Baltic countries and the EU, NATO, OSCE and UN would develop. The document emphasized the need to manage security regionally, to increase military investments, actively support cybernetic security and re-install regular military troops on Gotland. It was emphasized that a change in the approach towards Sweden's security resulted from the worsening situation in Europe, its complexity and unpredictability. It was remarked that a direct Russian attack on Sweden was not likely, yet considering Russia's aggressive policy it could not be ruled out (Government Offices of Sweden, 2015).

On the one hand, Sweden limited its understanding of neutrality to military non-participation in defense treaties; on the other hand, it strengthened its cooperation with NATO. At present it is confirmed that the participation by Swedish troops in multilateral military exercises in the Baltic region: BALTOPS (2013-2018), Saber Strike, Baltic Region Training Event (BRTE), Nordic Arctic Challenge and Cold Response; will be included. Sweden's armed forces are today designed to fit into a NATO-led operational framework. All forms of co-operation, schooling and training are involved (Huldt, 2003, p. 50; NATO, 2013). Sweden has also been building its security at a regional scale. For instance, in 2015 it signed a new agreement about permanent cooperation with Finland, assuming, 
among other elements, common exercises of all kinds of military force, participation in peacemaking operations, common research projects and common orders of armament and military equipment.

In 2017, the European Centre of Excellence for Countering Hybrid Threats (Hybrid CoE) in Helsinki was founded which brings together twelve countries (including Sweden) which cooperate to ensure cybernetic defense. Its analyses concern a comprehensive description of hybrid threats (military and nonmilitary aspects, disinformation actions, defense of critical infrastructure, cybernetic threats), the identification of spheres of social and economic life which are prone to the effects of such threats, looking for ways of increasing the resilience of participants to cyber-attacks (Hybrid CoE, 2017). In 2017, the greatest military exercises to be held in Sweden in years were organized under the name Aurora 17. Particular kinds of military forces were trained in how to cooperate, for instance, in defending the coast and the capital city (in the region of Stockholm and Gotland), conflict on the sea and (most notably) accepting military help from third parties. The exercises brought together about 2000 foreign soldiers, including 1300 from the USA (Swedish Armed Forces, n.d.). Additionally, after an eight-year break compulsory military service returned in Sweden in 2018 for both men and women.

One Swedish strategic aim is to strengthen cooperation within the EU, including the development of external ability of crisis management of the EU (Czarny, 2018, pp. 133-137). Sweden is also participating in the Permanent Structural Cooperation (PESCO), established in 2017, which is part of the European Union (EU) security and defense policy (EDA, n.d). The Swedish minister of foreign affairs Margot Wallström, in her address in parliament in February 2019, said: “Sweden's security begins in Europe. EU cooperation gives us peace, stability and growth (...). In a changing world, our task is to pursue a foreign policy that creates security in Sweden and around us. To do this, foreign policy (...) will have three priorities: the promotion of democracy, shared responsibility for peace and security, and active diplomacy" (Swedish Ministry for Foreign Affairs, 2019). Another Swedish aim is to maintain American engagement in the security of this part of Europe. Intensifying cooperation with the USA is treated as an alternative to full NATO membership. Such a 'pro-American non-alliance' (Gotkowska \& Szymański, 2016) has become a special challenge since Donald Trump has been elected president of the USA. His statements at the beginning of his term confirmed that he was not particularly keen on the USA defending Europe (Pace \& Lemire, 2017). As a consequence, Sweden and Finland have decided to ensure their security not only through cooperation with the USA but also 
with other members states of NATO. It is worth emphasizing that there has been long-lasting cooperation (started during the Cold War) between Sweden and Great Britain. For the latter, the northern flank of NATO is of key importance for defending Great Britain against a potential attack from the east (Czarny, 2017, pp. 143-144). In this context, the UK leaving the EU (Brexit) will limit possible British military assistance for Sweden to only acting through NATO, which might be treated as an argument for its membership of the treaty organization (Chaney, 2017, pp. 53-54).

\section{Conclusion}

The ever-changing international milieu has an influence on the flexibility of neutral states and the adaptive steps they take. Such states develop their own solutions, shaping customary norms. As a consequence, the traditional formal division into temporary and permanent neutrality as well as a neutral policy loses its significance. As observed by Dariusz Popławski, a Polish scholar specializing in this problem, discussing permanent neutrality as an international legal status in the $21^{\text {st }}$ century is in fact only historical. This is because at present we are witnessing a shift in contemporary neutrality from the legal to the political. The core of neutrality does not consist in isolation but in taking action in order to maintain peace and international security (Popławski, 2013, p. 22). Currently, neutrality as traditionally understood is a relic of the past, and the creation of new "models" is a result of states adapting to the changing situation related to security.

This is confirmed by the Swedish case, as for years the country has been conducting a specific political game in order to benefit from its status. It should be remembered that the evolution of Sweden's neutrality was primarily based on abandoning economic neutrality, then on modifying the military aspect, to finally transform itself into active non-alliance. In joining the EU Sweden has in some way entered a political alliance which includes elements of common military action, and the further development of European defense abilities will deform the idea of Swedish non-alliance.

Combating contemporary threats, such as international terrorism, hybrid wars or cybernetic attacks, requires states to cooperate and show solidarity and this constitutes a challenge for the non-allied as such circumstances encourage states to look for support from stronger allies, anchoring themselves in structures that may guarantee security. This is manifested in stronger cooperation between 
Sweden (and also Finland and Austria) with NATO, and its possible membership, issues which have been discussed for years (for more see: Trossmark, 2018).

Despite a long tradition of neutrality, treated as an element of Swedish national identity, as subsequent threats and challenges for security have appeared, social support for Sweden joining NATO has been on the increase: in 2012 it was $17 \%$, in 2013 - 29\% (Sobczyk, 2015, p. 59), while in 2015 - 41\% (Gummesson, 2015)). This support has remained at a similar level for several years; in 2019 it was $42 \%$ (Kaljurand, 2019). As might be suspected, if Russia triggers a crisis in the Baltic region which will directly threaten Sweden, the latter will naturally look for protection granted by NATO. Because of its engagement in cooperation with the treaty organization, Sweden seems to be expecting reciprocity in case of security problems. Thus, it is worth asking the question: is Sweden's formal membership of NATO indispensable for the organization (and especially the USA) to react favorably with regard to Sweden's interests? If the answer is "no," the Swedes, out of pragmatism, will probably still maintain their formal, specific policy of neutrality, which however is illusionary in many aspects.

\section{REFERENCES}

Bildt, C. (2018, Oct 18). The end of Scandinavian non-alignment. The Strategist [blog]. Australian Strategic Policy Institute. Retrieved from https://www.aspistrategist.org. au/the-end-of-scandinavian-non-alignment/

Bjereld, U., \& Ekengren, A. M. (2004). Cold War Historiography in Sweden. In T. B. Olesen (Ed.), The Cold War and the Nordic Countries: Historiography at a Crossroads, (pp. 143-175). Odense: University Press of Southern Denmark.

Chaney, K. A. (2017). NATO or Neutrality? Decisions by Denmark, Finland, Norway, and Sweden [MA thesis]. Monterey, CA: Naval Postgraduate School, September 2017. Retrieved from https://apps.dtic.mil/dtic/tr/fulltext/u2/1046807.pdf

Czarny, R. M. (2017). Neutrality in Swedish Foreign Policy in the Postwar Twenty Years. Studia i Materiały Wydziału Zarządzania i Administracji Wyższej Szkoły Pedagogicznej im. Jana Kochanowskiego w Kielcach, 4(2), 133-150.

Czarny, R. M. (2018). Sweden: From Neutrality to International Solidarity. Springer International Publishing. DOI 10.1007/978-3-319-77513-5

European Defence Agency (EDA). (n.d.). European Permanent Structural Cooperation (PESCO). Retrieved from https://www.eda.europa.eu/what-we-do/our-current-priorities/permanent-structured-cooperation-(pesco)

European External Action Service (EEAS). (2016). Shared Vision, Common Action: A Stronger Europe. A Global Strategy for the European Union`s Foreign and Security 
Policy. Retrieved from https://eeas.europa.eu/topics/eu-global-strategy/17304/global-strategy-european-unions-foreign-and-security-policy_en

Federal Department of Defence, Civil Protection and Sports (DDPS) in conjunction with the Federal Department of Foreign Affairs (n.d.). Swiss Neutrality [Brochure]. Retrieved from https://www.eda.admin.ch/dam/eda/en/../Swiss\%20neutrality.pdf

Gotkowska, J., \& Szymański, P. (2016, Mar 31). Proamerykańska bezaliansowość. Szwecja i Finlandia rozszerzają współpracę wojskową z USA. Komentarze OSW.

Government Offices of Sweden. (2015). The Swedish Defense Bill 2016-2020. Retrieved from https://www.government.se/government-policy/defence/the-swedish-defencebill-2016-2020/

Gummesson, J. (2015, 13 Sep). Stärkt opinion för Natomedlemskap, Svenska Dagbladet. Retrieved from https://www.svd.se/starkt-opinion-for-natomedlemsskap

Huldt, B. (2003). Comments on the Swedish positions, In H. Ojanen (Ed.), Neutrality and non-alignment in Europe today, (pp. 46-51). The Finnish Institute of International Affairs Report No. 6, Helsinki: The Finnish Institute of International Affairs. Joenniemi, P. (1993). Neutrality beyond the Cold War. Review of International Studies, 19(3).

Kaljurand, R. (2019). The Hem and Haw of Sweden`s Relationship with NATO. ICDS International Centre for Defence and Security. Retrieved from https://icds.ee/thehem-and-haw-of-swedens-relationship-with-nato/

Karsh, E. (1988). Neutrality and Small States. London: Routledge.

Kobierecka, A. (2016) Uwarunkowania szwedzkiej polityki neutralności. Polityka i Spoteczeństwo, 4, 141-154.

Malmborg, M. (2001). Neutrality and State-building in Sweden. Palgrave Macmillan UK. DOI $10.1057 / 9781403900920$

NATO. (2013, Jan 14). Sweden: one of NATO's most active and effective partners. Retrieved from https://www.nato.int/cps/en/natolive/news_93853.htm

Pace, J., \& Lemire, J. (2017). Trump scolds fellow NATO leaders: Spend more for military. Retrieved from https://apnews.com/2ed02clee7c64061a2bf146bfb0a4b2c/ Trump-scolds-fellow-NATO-leaders:-Spend-more-for-military

Popławski, D. (2013). Między bezstronnościa a solidarnościa międzynarodową. Polityka bezpieczeństwa państw neutralnych i bezaliansowych po zimnej wojnie, Warszawa: Scholar.

Sobczyk, K. (2015). Polityka bezpieczeństwa Szwecji - neutralność i bezaliansowość oraz ich perspektywy w obliczu konfliktu rosyjsko-ukraińskiego. Bezpieczeństwo narodowe, 4, 41-61.

United Nations Peacekeeping (n.d.). Sweden. Retrieved from https://peacekeeping.un.org/ en/sweden

Statista. (2019). Exports of arms from Sweden in 2017, by country. Retrieved from https:// www.statista.com/statistics/865459/exports-of-arms-from-sweden-by-country/ 
Swedish Armed Forces. (2017). Current International Missions. Retrieved from https:// www.forsvarsmakten.se/en/activities/current-international-missions2/

Swedish Armed Forces. (n.d.). AURORA 17. Stronger Defence Together. Retrieved from https://www.forsvarsmakten.se/en/activities/exercises/aurora-17/

Swedish Ministry for Foreign Affairs (2019). The Government's Statement of Foreign Policy 2019. Retrieved from https://www.government.se/speeches/20192/02/thegovernments-statement-of-foreign-policy-2019/

The European Centre of Excellence for Countering Hybrid Threats (Hybrid CoE). (2017). What Is Hybrid Coe? Retrieved from https://www.hybridcoe.fi/what-is-hybridcoe/

Trossmark, R. (2018, 3 Apr). Swedish Membership in NATO?: To be or not to be? Reviewing the perspectives in the Swedish debate. The Perspective. Retrieved from http://www.theperspective.se

Wezeman, P. D., Fleurant, A., Kuimova, A., Tian, N., \& Wezeman, S. T. (2018), Trends in International Arms Transfers 2017. SIPRI Fact Sheet March 2018. Retrieved from https://www.sipri.org/publications/2018/sipri-fact-sheets/trends-internationalarms-transfers-2017

Wezeman, P. D., Fleurant, A., Kuimova, A., Tian, N., \& Wezeman, S. T. (2019), Trends in International Arms Transfers 2018. SIPRI Fact Sheet, March 2019. Retrieved from https://www.sipri.org/publications/2019/sipri-fact-sheets/trends-internationalarms-transfers-2018 